\title{
RESISTANCE TO BIOTIC FACTORS AND YIELD CAPACITY OF SPRING BARLEY VARIETIES IN THE EASTERN FOREST-STEPPE OF UKRAINE
}

Solonechnaya O. V.

Plant Production Institute nd. a V. Ya. Yuriev of NAAS, Ukraine

The paper investigates resistance of varieties to biotic factors as well as their yield capacity.

The aim and tasks of the study. Selection of high-yielding starting material for breeding for genetic protection against major pathogens and pests.

Materials and methods. The investigations were carried out in 2013-2015 in the Laboratory of Resistance to Biotic Factors of the Plant Production Institute nd. a VYa Yuriev of NAAS on artificial infectious and provocative backgrounds. The study material was 29 spring barley varieties of domestic and foreign breeding. The yield capacity of the varieties was evaluated in a competitive variety trail.

Results and Discussion. The assessment highlighted varieties with individual, group and complex protection against pathogens and pests (Pan, Veles, Vzirets, Skarb, Dokaz, Komandor, Agrariy, Vsesvit, Kangoo, Ksanadu, Sofiara, Shakira, Arikada, Pasadena, Mauritia, Novosadsky 294). We distinguished varieties, the yield capacity of which significantly exceeded that of the national standard 'Vzirets', (Veles, Skarb, Pan, Alegro, Novosadskiy 294, Smaragd, Shakira, Mauritia) as well as varieties noticeable for individual, group or complex resistance to pathogens of certain diseases and intra-stem pests.

Conclusions. As a result, varieties - sources of individual, group and complex resistance as well as varieties combining high yield capacity and resistance to biotic factors in one genotype (Veles, Pan, Alegro, Novosadskiy 294, Smaragd, Shakira, Skarb, and Mauritia), which can be used in breeding as starting material, were identified.

Key words: spring barley, variety, yield capacity, disease, pest, group and complex resistance

УДК: 633.1: 575

ОСОБЛИВОСТІ НАЛИВУ ТА ФОРМУВАННЯ ВРОЖАЙНОСТІ ЗЕРНА В СУЧАСНИХ СОРТІВ ПШЕНИЦІ ТВЕРДОЇ ЯРОЇ

Усов О. С.

Інститут рослинництва ім. В. Я. Юр'єва НААН, м. Харків, Україна

У трирічних дослідах (2013-2015 рр.) лабораторії рослинництва та сортовивчення Інституту рослинництва ім. В. Я. Юр'єва НААН вивчено динаміку накопичення пластичних речовин у зерні сучасних сортів пшениці твердої ярої та належності їх до екотипів адаптивності. Встановлено, що всі досліджувані сорти пшениці твердої ярої максимальну кількість пластичних речовин в зерні накопичують у фазу молочного стану та належать до лісостепового екотипу.

Ключові слова: пшеничя тверда яра, екотип, налив зерна, фаза розвитку, сорт, урожайність

Вступ. Вирощування будь-якої сільськогосподарської культури та отримання високого і якісного врожаю неможливе без знання біологічних особливостей рослини та ії складових, найважливішою з яких є зерно.

(C) О. С. Усов. 2015.

ISSN 0582-5075. Селекція і насінництво. 2015. Випуск 108. 
Аналіз літературних джерел, постановка проблеми. Роботами відомих учених установлено загальні принципи зерноутворення $[1,2,3,4]$. Дослідники розділили весь процес утворення зерна на три етапи: формування, налив та стиглість. Етапи зерноутворення мають фази розвитку, які включають передмолочну, молочну, тістоподібну і воскову консистенцію та повну стиглість. Зерно в різні етапи та фази свого розвитку характеризується певною будовою та рівнем вологості, яка є основним показником його стану і фази розвитку. Так, за вологості зерна до $70 \%$ зерно находиться у фазі передмолочного стану (формування зерна), 69-50 \% - у фазі молочного стану, 49-35 \% - у фазі тістоподібного стану, 34-20 \% - у фазі воскового стану, 19-18 \% - у фазі повної стиглості [3]. Сутність та складові цього процесу залежать не тільки від генетично-біологічних особливостей, а також від нерегульованих (температура, опади, вологість та ін.) та регульованих (попередник, фон мінерального живлення, обробіток грунту та ін.) факторів середовища, які в значній мірі зумовлюють урожайність та якість зерна.

У процесі розвитку, наливу і достигання зерна відбувається формування його якості. Процес формування зерна характеризується безперервним приростом сухої речовини, який відбувається завдяки надходженню в зерно з листків та інших вегетативних органів рослин органічних речовин і мінеральних елементів. Динаміку накопичення сухої речовини вивчали багато дослідників, але відносно закінчення приросту сухої речовини в зерні єдиної думки немає. Вважається, що маса 1000 зерен досягає максимальної величини у фазу воскового стану, за вологості зерна близько 40 \% $[5,6,7]$. Проте, згідно інших даних, накопичення сухої речовини за відповідних умов триває до повної стиглості зерна $[3,8,9]$. Існують дані про зниження маси 1000 зерен після досягнення максимальної величини, що пов'язано з процесами «стікання» зерна, вимиванням і вилужуванням (визолюванням) поживних речовин внаслідок біохімічних процесів у зерні, розвитку патогенної мікрофлори на його поверхні та відтоку поживних речовин із зерна через стебла і корені в грунт, що буває в період, коли ще не відбулося відокремлення зерна від материнського організму $[6,10]$.

Мета і задачі досліджень. Метою досліджень було встановлення динаміки наливу зерна, визначення екотипової належності сучасних сортів пшениці твердої ярої, визначення кореляції між урожайністю та масою 1000 зерен.

Матеріали і методи. Досліди проводили в стаціонарній паро-зерно-просапній сівозміні лабораторії рослинництва і сортовивчення Інституту рослинництва ім. В. Я. Юр'єва НААН після попередника буряки цукрові протягом 2013-2015 pp. на фонах без добрив та післядії 30 т/га гною із внесенням мінеральних добрив у дозі $\mathrm{N}_{60} \mathrm{P}_{60} \mathrm{~K}_{60}$. Досліди закладали за багатофакторними схемами методом розщеплених ділянок з урахуванням усіх вимог методики польового досліду $[11,12]$. Налив зерна пшениці твердої ярої визначали згідно методики визначення агроекологічної пластичності сортів [13]. Об'єктами досліджень були сорти пшениці твердої ярої селекції Інституту рослинництва ім. В. Я. Юр'єва Спадщина, Династія і Новація та сорти селекції Миронівського інституту пшениці ім. В. М. Ремесла Ізольда та Жізель. Облікова площа ділянок $25 \mathrm{~m}^{2}$, повторення триразове. Технологія вирощування - загальноприйнята для східної частини Лісостепу України, окрім досліджуваних елементів. Статистичний аналіз даних урожайності проводили за Б. А. Доспеховым [12].

Грунт дослідної ділянки - чорнозем типовий глибокий слабовилугований на пилувато-суглинковому лесі, який характеризується зернисто-грудкуватою структурою, хорошими фізико-механічними властивостями. Вміст гумусу (за Тюріним) складає $5,8 \%$; $\mathrm{pH}-5,8 ;$ гідролітична кислотність - 3,29 мг-екв на 100 г грунту.

Обговорення результатів. Одним із важливих показників визначення рівня зволоження протягом певного періоду $є$ гідротермічний коефіцієнт $\Gamma$. Т. Селянинова (ГТК). Середньобагаторічний ГТК для зони Лісостепу складає 1,0.

За вегетаційний період пшениці твердої ярої в 2013-2015 рр. гідротермічний коефіцієнт становив $0,57,1,44$ та 1,15 за роками (рис. 1). Таким чином, найсприятливішим, добре зволоженим для розвитку пшениці твердої ярої виявився період вегетації 2014 р. (ГТК $=1,44)$, а несприятливим посушливим відзначився період вегетації 2013 року - ГТК становив 0,57. Вегетаційний період 2015 року був оптимальним за рівнем зволоження - ГТК 1,15 . 




Рис. 1. Гідротермічний коефіцієнт за періоди вегетації пшениці твердої ярої у роки досліджень порівняно із середньобагаторічною нормою

У фазу передмолочного стану (формування зерна) найбільшою маса 1000 зерен на фоні без добрив була у сортів Жізель, Новація та Спадщина - 10,5 г, 10,6 г та 10,8 г відповідно (рис. 2). Інтенсивність наливу зерна становила у сорту Спадщина 1,19 г/добу, у сортів Жізель та Новація - 1,17 г/добу (рис. 3). Сорт Ізольда найменше накопичував сухих речовин у цей період - 7,5 г, а сорт Династія - 9,3 г. Інтенсивність наливу в цих сортів становила 0,93 г/добу та 1,03 г/добу відповідно. 3 внесенням мінеральних добрив маса 1000 зерен у сортів пшениці твердої ярої підвищувалася на 2,5 г, 2,2 г, 2,4 г, 1,4 г та 3,4 г та становила 13,3 г, 9,7 г, 12,9 г, 10,7 г та 14,0 г відповідно до сортів Спадщина, Ізольда, Жізель, Династія та Новація (рис. 4). Інтенсивність наливу з внесенням добрив також підвищувалася та становила 1,20 г/добу, 1,21 г/добу, 1,29 г/добу, 1,07 г/добу та 1,40 г/добу відповідно до сортів Спадщина, Ізольда, Жізель, Династія та Новація (рис. 5).

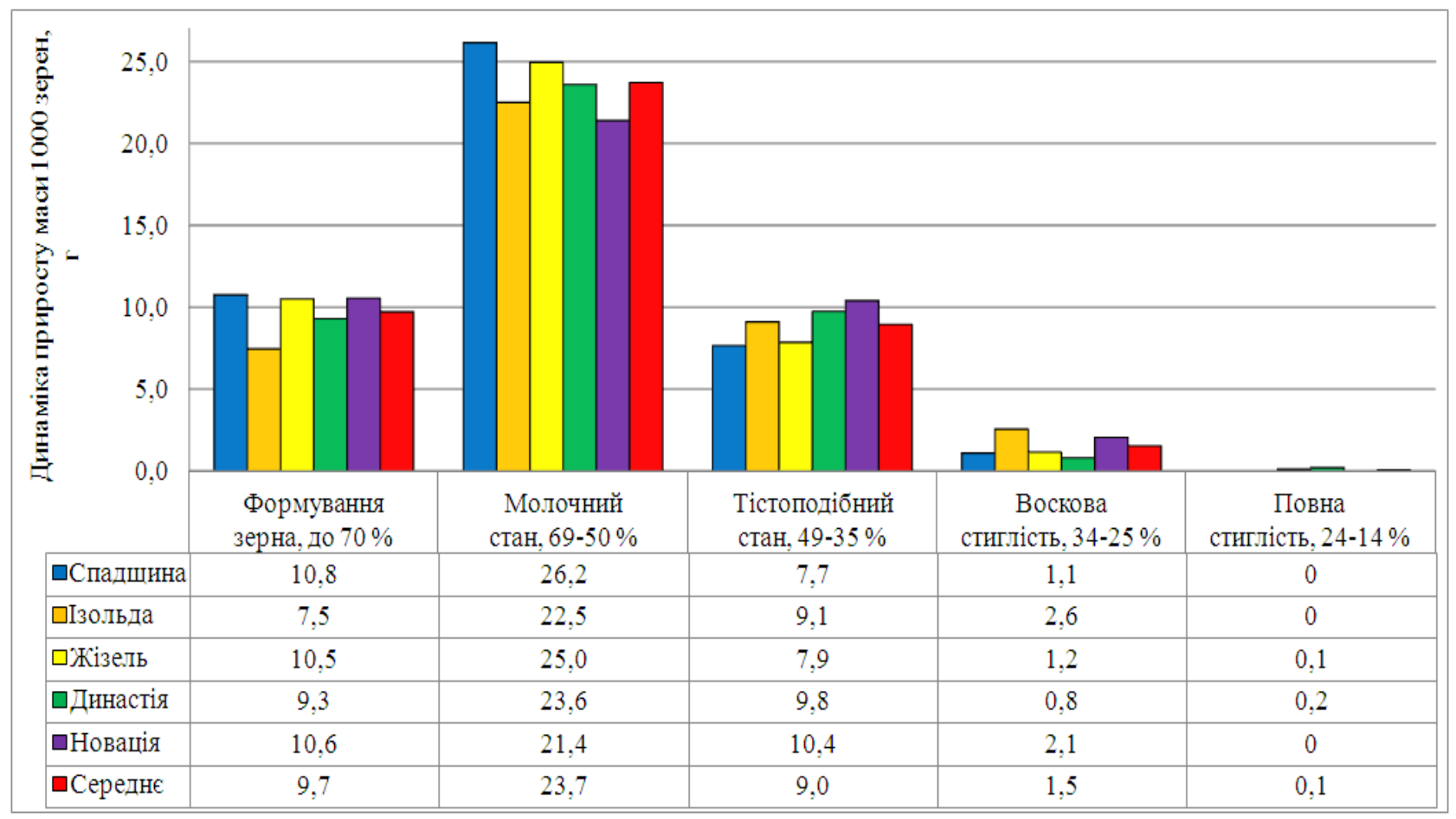

Рис. 2. Динаміка приросту маси 1000 зерен сортів пшениці твердої ярої на фоні без добрив, г, 2013-2015 pp. 


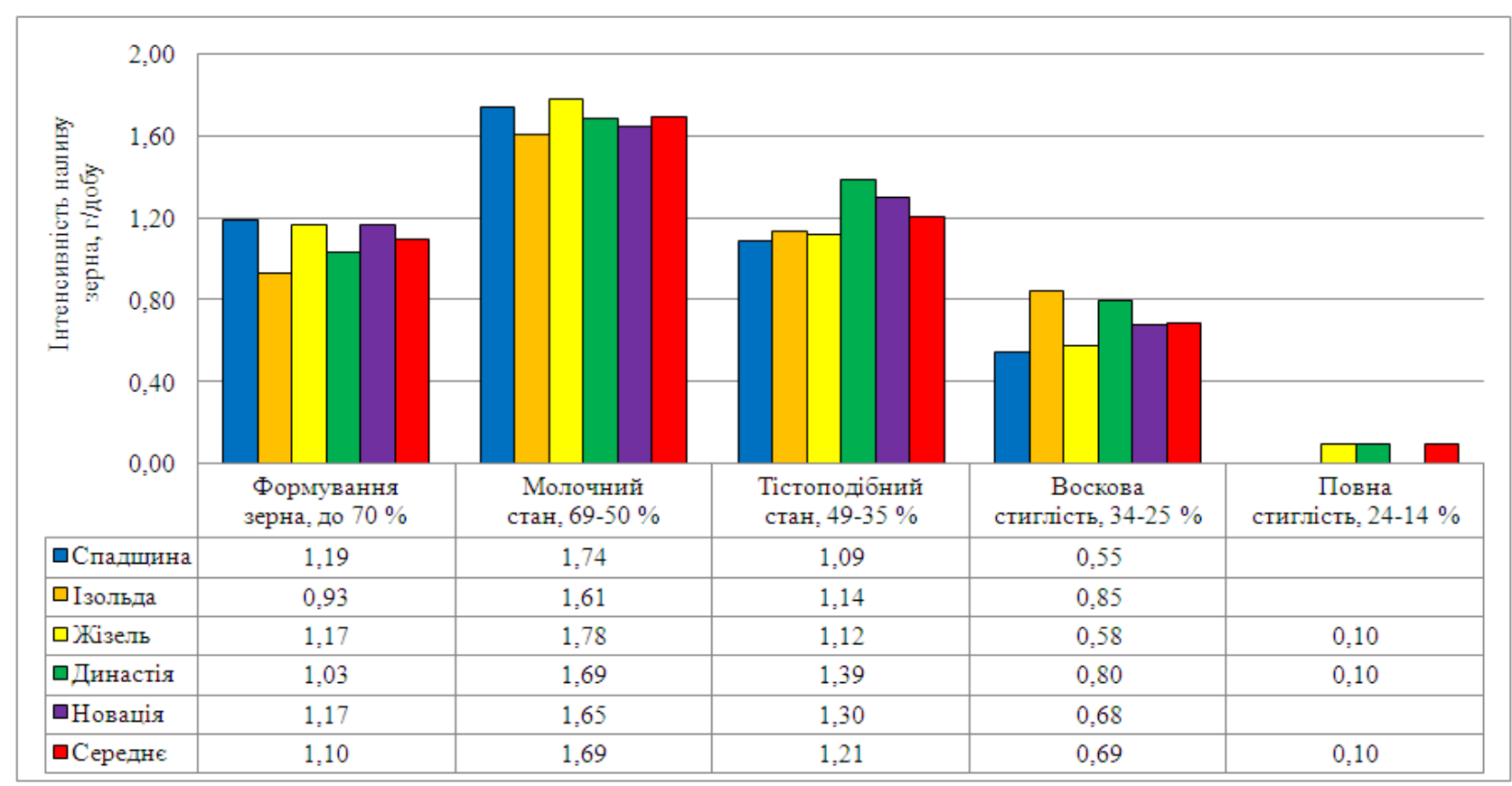

Рис. 3. Інтенсивність наливу маси 1000 зерен сортів пшениці твердої ярої на фоні без добрив, г, 2013-2015 рр.

Установлено, що всі досліджувані сорти пшениці твердої ярої мають чітку належність до лісостепового екотипу, оскільки максимальну кількість пластичних речовин в зерні вони накопичували у фазі молочного стану (69-50 \% вологість зерна) незалежно від фону живлення. Ріст маси 1000 зерен у цей період в середньому по сортах становив 23,7 г на фоні без добрив та 21,4 г на фоні післядії гною з внесенням мінеральних добрив у дозі $\mathrm{N}_{60} \mathrm{P}_{60} \mathrm{~K}_{60}$. Найбільше сухих речовин в цей період на фоні без добрив накопичував сорт Спадщина - 26,2 г, інтенсивність наливу зерна становила 1,74 г/добу, а на фоні 3 внесенням добрив сорт Ізольда - 25,7 г, інтенсивність наливу - 1,83 г/добу.

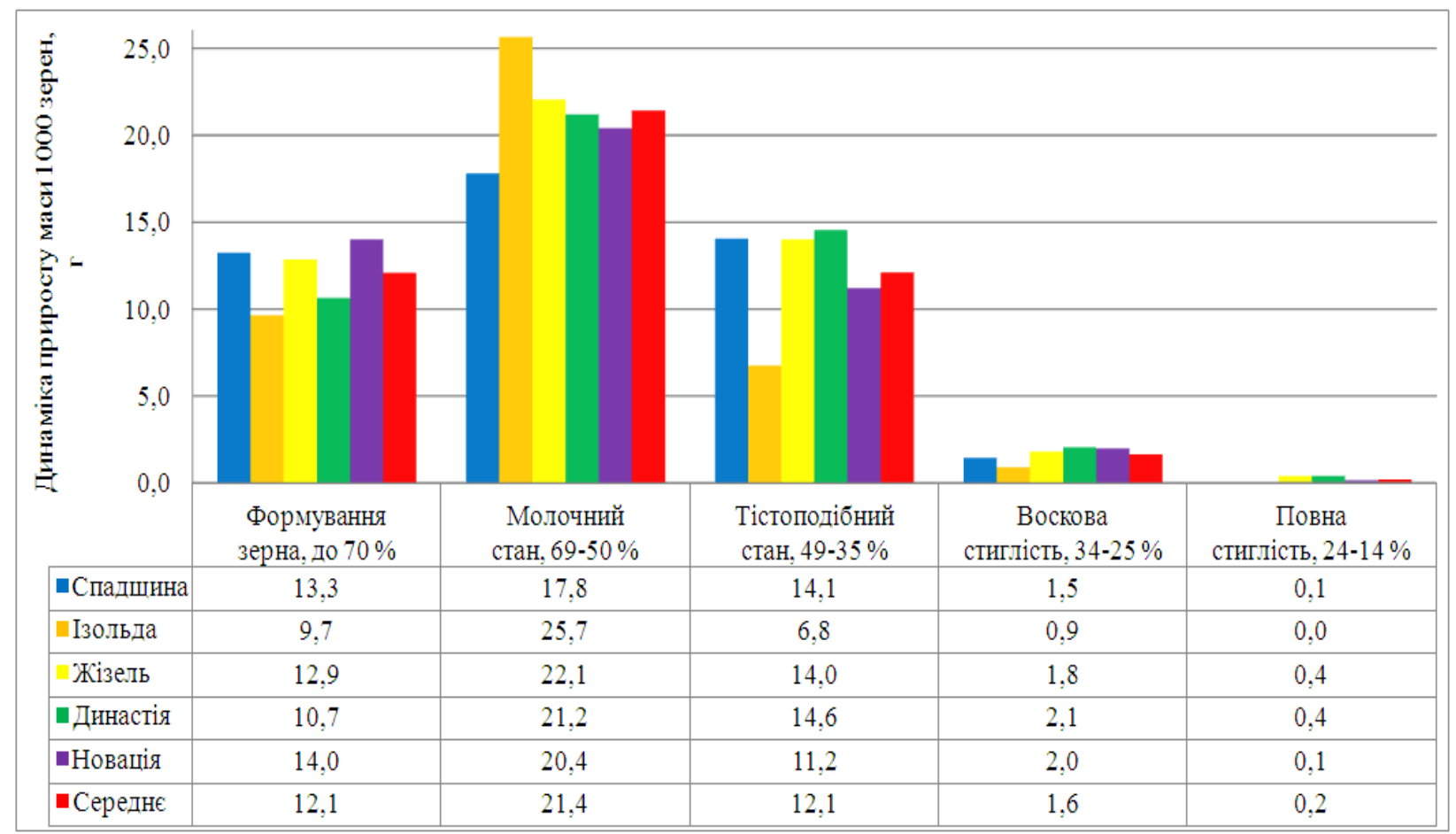

Рис. 4. Динаміка приросту маси 1000 зерен сортів пшениці твердої ярої на фоні живлення фон $+\mathrm{N}_{60} \mathrm{P}_{60} \mathrm{~K}_{60}, \Gamma, 2013-2015 \mathrm{pp}$. 
У фазу тістоподібного стану (вологість зерна 49-35 \%) всі сорти, окрім сорту Ізольда, забезпечували ріст маси 1000 зерен на фоні з внесенням мінеральних добрив більше від фону без добрив. Так, найбільше збільшення приросту маси 1000 зерен у порівнянні з фоном без добрив було у сортів Спадщина та Жізель - 6,4 г та 6,2 г, вона становила 14,1 г та 14,0 г на фоні із внесенням $\mathrm{N}_{60} \mathrm{P}_{60} \mathrm{~K}_{60}$. Найбільший приріст маси 1000 зерен забезпечували сорти Династія - 14,6 г на фоні з внесенням добрив, Новація - 10,4 г на фоні без внесення добрив. У сорту Ізольда на фоні без добрив приріст маси 1000 зерен становив 9,1 г, що більше порівняно з фоном з внесенням добрив на 2,4 г.

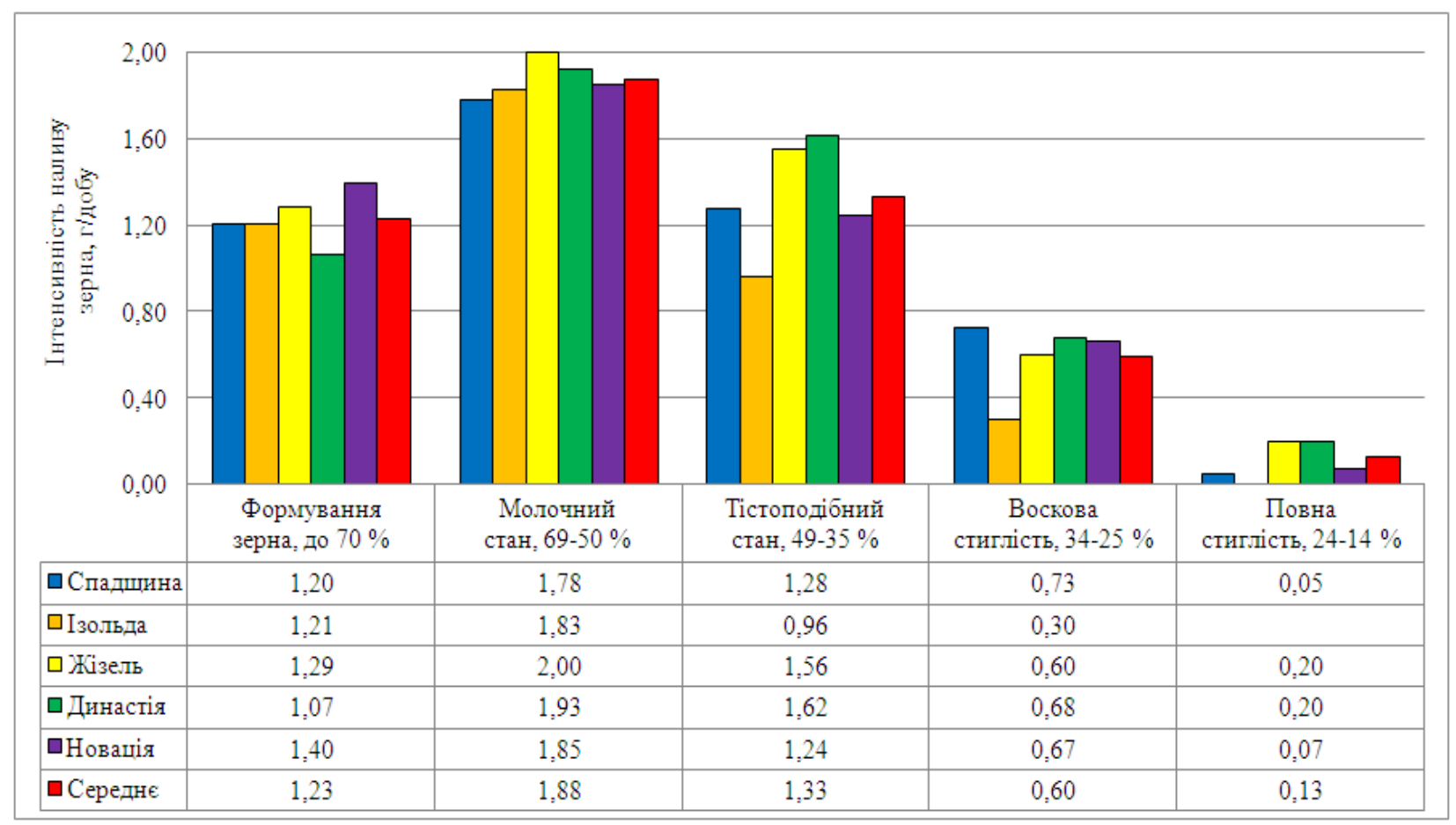

Рис. 5. Інтенсивність наливу маси 1000 зерен сортів пшениці твердої ярої на фоні без добрив, г, 2013-2015 pp.

На фоні без добрив до фази повної стиглості зерна (вологість зерна 24-14 \%) сорти Спадщина, Ізольда та Новація завершили накопичення сухих речовин та сформували масу 1000 зерен на рівні 45,7 г, 41,6 г та 44,4 г відповідно, а сорти Жізель та Династія продовжували накопичення сухих речовин та мали зростання показника маса 1000 зерен на 0,1 г та 0,2 г (табл. 1). У цей період на фоні з внесенням добрив, у всіх сортів збільшувалася маса 1000 зерен в середньому на 0,2 г, окрім сорту Ізольда, який сформував масу 1000 зерен 43,0 г. Найбільшу масу 1000 зерен відмічено у сорту Жізель - 51,1 г. За період наливу зерна інтенсивність накопичення сухих речовин на фоні без добрив коливалася в межах 0,58-1,74 г/добу, а на фоні із внесенням мінеральних добрив 0,60-2,0 г/добу залежно від сорту та фази розвитку.

Таким чином, установлено, що всі досліджувані сорти пшениці твердої мають належність до лісостепового екотипу адаптивності, тобто для найбільш раціонального їх використання у виробництві та забезпечення формування високого рівня врожайності зерна кращою зоною є Лісостеп України, оскільки дані сорти спроможні витримувати тривалі посухи.

Дослідженнями встановлено, що зі збільшенням маси 1000 зерен при внесенні мінеральних добрив збільшується і врожайність сортів пшениці твердої ярої. Між масою 1000 зерен та врожайністю встановлено негативні середні зв'язки на рівні r=-0,48 та r=-0,68 відповідно до фонів живлення (табл. 1).

Проведені дослідження за 2013-2015 pр. із сучасними сортами пшениці твердої ярої на сівозмінному фоні без добрив (контроль) дозволили виявити достовірне зниження врожайності у сорту Новація на 0,27 т/га у порівнянні з середньою врожайністю по сортах $\left(\mathrm{HIP}_{05}=0,27\right.$ т/га). Урожайність решти сортів була в межах похибки досліду. На удобрено- 
му фоні та в середньому за фонами суттєвої різниці між сортами не виявлено, урожайність зерна коливалась в межах різниці НІР.

Застосування добрив найбільше впливало на формування врожайності зерна сортів пшениці твердої ярої, прибавка складала в середньому 0,85 т/га, що суттєво перевищувало $\operatorname{HIP}(0,17 \mathrm{т} / г \mathrm{a})$.

Таблиця 1

Урожайність та маса 1000 зерен сортів пшениці твердої ярої в залежності від фону живлення, 2013-2015 pр.

\begin{tabular}{|c|c|c|c|c|c|c|c|c|}
\hline \multirow[b]{3}{*}{ Сорт (B) } & \multicolumn{4}{|c|}{ Фони живлення (А) } & \multirow{2}{*}{\multicolumn{2}{|c|}{$\begin{array}{c} \pm \text { до контро- } \\
\text { лю } \\
\end{array}$}} & \multirow{2}{*}{\multicolumn{2}{|c|}{$\begin{array}{c}\text { Середнє по } \\
\text { сорту }\end{array}$}} \\
\hline & \multicolumn{2}{|c|}{ без добрив } & \multicolumn{2}{|c|}{$\phi \mathrm{OH}+\mathrm{N}_{60} \mathrm{P}_{60} \mathrm{~K}_{60}$} & & & & \\
\hline & 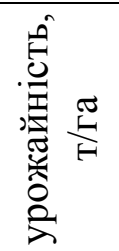 & 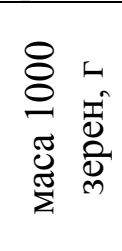 & 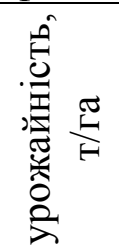 & 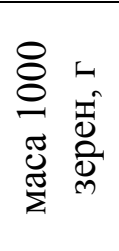 & 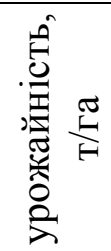 & 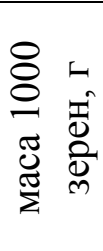 & 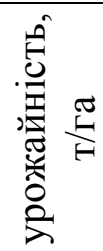 & 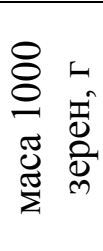 \\
\hline Спадщина & 2,66 & 45,7 & 3,35 & 46,6 & 0,69 & 0,9 & 3,01 & 46,1 \\
\hline Ізольда & 2,81 & 41,6 & 3,67 & 43,0 & 0,86 & 1,4 & 3,24 & 42,3 \\
\hline Жізель & 2,61 & 44,6 & 3,44 & 51,1 & 0,83 & 6,6 & 3,03 & 47,8 \\
\hline Династія & 2,60 & 43,7 & 3,39 & 48,9 & 0,79 & 5,2 & 2,99 & 46,3 \\
\hline Новація & 2,33 & 44,4 & 3,39 & 47,8 & 1,06 & 3,3 & 2,86 & 46,1 \\
\hline Середнє по фону & 2,60 & 44,0 & 3,45 & 47,5 & 0,85 & 3,5 & 3,03 & 45,7 \\
\hline \multicolumn{2}{|l|}{$\mathrm{r}_{\text {з урожайністю }}=$} & $-0,48$ & & $-0,68$ & & & & \\
\hline \multicolumn{9}{|c|}{$\mathrm{HIP}_{05}$ за факторами для урожайності: $\mathrm{A}-0,17$ т/га, В - 0,27 т/га, $\mathrm{AB}-0,38$ т/га } \\
\hline \multicolumn{9}{|c|}{ HIP $_{05}$ за факторами для маси 1000 зерен: $\mathrm{A}-0,98$ г, В - 1,54 г, AB - 2,18 г } \\
\hline
\end{tabular}

За показником маси 1000 зерна відмічено, що на фоні без застосування добрив сорт Спадщина достовірно перевищував середній показник по сортах на 1,7 г, а сорт Ізольда знижував на 2,4 г при $\mathrm{HIP}_{05}=0,98$ г. За удобрення, встановлено, що сорти пшениці твердої ярої Жізель та Династія достовірно перевищували даний показник у порівнянні з середнім на 3,6 г та 1,4 г. В середньому за фонами живлення, встановлено, що показник маси 1000 зерен порівняно з середнім у сортів пшениці твердої ярої варіював в межах різниці НІР, окрім сорту Ізольда у якого встановлено достовірне зниження у порівнянні з середнім на 3,4 г при $\mathrm{HIP}_{05}=2,18$ г.

Внесення добрив сприяло підвищенню маси 1000 зерен у сортів пшениці твердої ярої в середньому на 3,5 г. найбільше зростання даного показника встановлено у сорту Жізель на 6,6 г при $\mathrm{HIP}_{05}=1,54$ г.

Висновки. Дослідженнями встановлено, що всі сорти пшениці твердої ярої мають приналежність до лісостепового екотипу. Найбільшу кількість сухих речовин сорти накопичували у фазу молочної стиглості зерна 21,4-26,2 г залежно від сорту та фону живлення.

Найбільшу масу 1000 зерен на фоні без добрив сформував сорт Спадщина 45,7 г, а на фоні з внесенням добрив $\mathrm{N}_{60} \mathrm{P}_{60} \mathrm{~K}_{60}$ сорт Жізель - 51,1 г. Врожайність, як і маса 1000 зерен збільшувалася з внесенням добрив у середньому по сортах на 0,85 т/га. Суттєвої різниці між сортами не встановлено, окрім фону без добрив, на якому сорт Новація формував достовірно нижчу врожайність у порівнянні з середньою по фону на 0,27 т/га при $\mathrm{HIP}_{05}=$ 0,27 т/га.

\section{Список використаних джерел}

1. Гриценко, В. В. Семеноведение полевых культур [Текст] / В. В. Гриценко. - М.: Колос, 1976. $-320 \mathrm{c}$.

2. Кулешов, Н. Н. Агрономическое семеноведенье [Текст] / Н. Н. Кулешов. - М.: Сельхозиздат, 1963. - 304 с. 
3. Строна, И. Г. Общее семеноведение полевых культур [Текст] / И. Г. Строна. - М.: Колос, 1966. $-463 \mathrm{c}$.

4. А. с. 113035 Способ агроэкологической оценки сортов [Текст] / В. М. Костромитин (Описание изобретения ВНИИПИ Госком СССР по делам изобретений и открытий). № 1055844. - M., 1983.

5. Каменева, Г. В. Качество зерна яровой пшеницы в зависимости от норм высева на различных уровнях питания [Текст] / Г. В. Каменева // Повышение урожая и качества зерна. - Горький, 1977. - С. 119-122.

6. Коренев, Г. В. Биологическое обоснование сроков и способов уборки хлебов [Текст] / Г. В. Коренев. - К.: Урожай, 1967. - 150 с.

7. Кулешов, Н. Н. Процесс зернообразования в связи с технологическими качествами урожая [Текст] / Н. Н. Кулешов // Вестник сельскохозяйственной науки. - 1964. - № 5. C. 28-33.

8. Кретович, В. Л. Физиолого-биохимические основы хранения зерна [Текст] / В. Л. Кретович. - М.- Л.: АН СССР, 1945. - 134 c.

9. Yamazaki, W. T. Soft wheat quality of preripe harvested wheat [Text] / W. T. Yamazaki // Crop. Sci. - 1976. - V. 16, № 4. - P. 572-574.

10.Крищенко, В. П. Интенсивная технология возделывания озимой и яровой пшеницы [Текст] / В. П. Крищенко. - М.: Высшая школа, 1986. - 80 с.

11.Методические рекомендации по изучению сортовой агротехники в селекцентрах [Текст]. подгот.: П. П. Литун, В. М. Костромитин, Л. В. Бондаренко. - М.: ВАСХНИЛ, 1984. - 32 с.

12.Доспехов, Б. А. Методика полевого опыта (с основами статистической обработки результатов исследований) [Текст] / Б. А. Доспехов. -5-е изд., доп. и перераб. - М.: Агропромиздат, 1985. - $351 \mathrm{c}$.

13.Метод определения агроэкологической пластичности сортов [Текст]: методические рекомендации; подгот.: В. М. Костромитин. - Х., 1985. - 14 с.

\section{References}

1. Gritsenko, VV. Seed field crops. Moscow: Kolos; 1976. 320 p.

2. Kuleshov, NN. Agronomic seed. Moscow: Selhozgiz; 1963. 304 p.

3. Strona, IG. Total of seed of field crops. Moscow: Kolos; 1966. 463 p.

4. Kostromitin, VM. Method of agro-ecological assessment grades. Moscow, 1983.

5. Kameneva, GV. The quality of grain of spring wheat depending on seeding rates at different levels of power. In: Increase yield and grain quality. Gorkiy, 1977. P. 119-122.

6. Korenev, GV. Biological basis of terms and methods of grain harvesting. Kyiv: Urozhay; 1967. $150 \mathrm{p}$.

7. Kuleshov NN. Process formation of grain in connection with the technological internalss of harvest. Vestnik selskohozyayistvennoyi nauki. 1964; 5: 28-33

8. Kretovich, VL. Physiological and biochemical basis of grain storage. Moscow-Leningrad: AN SSSR; 1945. $134 \mathrm{p}$.

9. Yamazaki WT. Soft wheat quality of preripe harvested wheat. Crop. Sci. 1976; 4: 572-574.

10.Krishhenko, VP. Intensive technology of till of winter and spring wheat. Moscow. Vysshaya shkola; $1986.80 \mathrm{p}$.

10.Litun PP, Kostromitin VM, Bondarenko LV. Guidelines for the study of agricultural technology in breeding centers graded. Moscow: All-Union Academy of agricultural crops, nd. a Lenin; 1984. 32 p.

11.Dospekhov, BA. Methods of field experience (with the fundamentals of statistical processing of the results of research). Moscow: Agropromizdat; 1985. $351 \mathrm{p}$.

12.Kostromitin, VM. Method for determination of agro ecological plasticity of varieties. Kharkiv, 1985. $14 \mathrm{p}$. 
Выращивание любой сельскохозяйственной культуры и получение высокого и качественного урожая невозможно без знания биологических особенностей растения и его составляющих, самой важной из которых является зерно.

Цель и задачи исследования. Целью исследований было выявление динамики налива зерна, установления экотипической принадлежности современных сортов пшеницы твердой яровой, установления корреляции между урожайностью и массой 1000 зерен.

Материалы и методы. Исследования проводили в 2013-2015 гг. в стационарном парозерно-пропашном севообороте лаборатории растениеводства и сортоизучения Института растениеводства им. В. Я. Юрьева НААН по многофакторной схеме методом расщепленных делянок с учетом всех требований методики полевого опыта. Предшественник - свекла сахарная на фонах без использования удобрений (контроль) и последействия 30 т/га навоза с внесением минеральных удобрений в дозе $\mathrm{N}_{60} \mathrm{P}_{60} \mathrm{~K}_{60}$. Налив зерна пшеницы твердой яровой определяли согласно методикам определения агроэкологической пластичности сортов.

Обсуждение результатов. За вегетационный период пшеницы твердой яровой 2013 2015 гг. гидротермический коэффициент по годам составил 0,57, 1,44 и 1,15. Таким образом хорошо увлажненным $(\Gamma T K=1,44)$, самым благоприятным для развития пшеницы твердой яровой оказался период вегетации 2014 года, а неблагоприятным засушливым - период вегетации 2013 года, ГТК составил 0,57. Вегетационный период 2015 был оптимальным по уровню увлажнения - ГТК 1,15.

Установлено, что все исследуемые сорта пшеницы твердой яровой имеют четкую принадлежность к лесостепному экотипу, поскольку максимальное количество пластических веществ в зерне они накапливали в фазе молочного состояния (69-50\% влажность зерна) независимо от фона питания. Прирост массы 1000 зерен в этот период в среднем по сортам составил 23,7 г на фоне без удобрений и 21,4 г на фоне последействия навоза с внесением минеральных удобрений в дозе $\mathrm{N}_{60} \mathrm{P}_{60} \mathrm{~K}_{60}$. Больше всего накапливал сухих веществ в этот период на фоне без удобрений сорт Спадщина - 26,2 г, интенсивность налива зерна составляла 1,74 г/сутки, а на фоне с внесением удобрений сорт Изольда - 25,7 г, интенсивность налива - 1,83 г/сутки.

Исследованиями установлено, что с увеличением массы 1000 зерен при внесении минеральных удобрений увеличивается и урожайность сортов пшеницы твердой яровой. Так, за годы исследований сортов на фоне без внесения минеральных удобрений средняя урожайность по сортам составила 2,60 т/га, а при внесении минеральных удобрений увеличивалась на 0,85 т/га и составила 3,45 т/га. На фоне без удобрений максимальная масса 1000 зерен сформировалась у сорта Спадщина - 45,7 г, а на фоне с внесением удобрений у сорта Жизель - 51,1 г, при урожайности этих сортов 2,66 т/га и 3,44 т/га соответственно.

Между массой 1000 зерен и урожайностью установлены отрицательные средние корреляционные связи на уровне $\mathrm{r}=-0,48$ и $\mathrm{r}=-0,68$ соответственно к фонам минерального питания.

Выводы. Исследованиями установлено, что все сорта пшеницы твердой яровой имеют принадлежность к лесостепному экотипу. Наибольшее количество сухих веществ сорта накапливали в фазу молочной спелости зерна 21,4-26,2 г в зависимости от сорта и фона минерального питания.

Наибольшую массу 1000 зерен на фоне без удобрений сформировал сорт Спадщина 45,7 г, а на фоне с внесением удобрений $\mathrm{N}_{60} \mathrm{P}_{60} \mathrm{~K}_{60}$ сорт Жизель - 51,1 г. Урожайность, как и масса 1000 зерен увеличивалась с внесением удобрений в среднем по сортам на 0,85 т/га. Существенной разницы между сортами не установлено, кроме фона без удобрений, на котором сорт Новация формировал урожайность в сравнении со средней на 0,27 т/га при $\mathrm{HCP}_{05}=0,27$ т/га.

Ключевые слова: пшенииа твердая яровая, экотип, налив зерна, фаза развития, сорт, урожайность 


\section{PECULIARITIES OF FILLING AND YIELD FORMATION IN MODERN VARIETIES OF DURUM SPRING WHEAT}

Usov O. S.

Plant Production Institute nd. a V. Ya. Yuriev of NAAS, Ukraine

Cultivation of any crop and achievement of a high top-quality yield are impossible without the knowledge of biological characteristics of the plant and its organs, the most important of which is grain.

The aim and tasks of the study. The aim was to identify the dynamics of grain filling, to establish ecotypic affiliation of modern accessories durum spring wheat, to find correlation between yield capacity and 1000-grain weight.

Materials and methods. The investigations were carried out in stationary fallow-grain row-crop rotation by the split plot method taking into account all requirements of the field experimentation methodology in the Laboratory of Plant Production and Variety Studies of the Plant Production Institute nd. a VYa Yuriev of NAAS in 2013-2015. Predecessor was sugar beet on without fertilizer (control) and with mineral fertilizers at the dose of $\mathrm{N}_{60} \mathrm{P}_{60} \mathrm{~K}_{60}$ after $30 \mathrm{t} / \mathrm{ha}$ of manure. Durum spring wheat grain filling was determined according to the techniques of determination of agro-ecological plasticity of varieties.

Results and discussion. During the growing season of durum spring wheat in 2013-2015, the yearly hydrothermal coefficient was $0.57,1.44$ and 1.15 . Thus, the growing season of 2014 was well-moistened $(\mathrm{HTC}=1.44)$ and turned out to be the most favorable for the development of durum spring wheat, and the growing season of 2013 was dry and unfavorable (HTC was 0.57). The vegetation period in 2015 was optimal in terms of moisture level $-\mathrm{HTC}=1.15$.

All the test durum spring wheat varieties were found to clearly belong to the forest-steppe ecotype, since the maximum amount of plastic substances in grain was accumulated in the milky stage (grain moisture 69-50\%), regardless of nutrition. The gain in 1000-grain weight during this period on average across the varieties was $23.7 \mathrm{~g}$ without fertilizers and $21.4 \mathrm{~g}$ with mineral fertilizers at the dose of $\mathrm{N}_{60} \mathrm{P}_{60} \mathrm{~K}_{60}$ after 30 t/ha of manure. Variety 'Spadschina' accumulated the highest amount of dry matter in this period without fertilizers - $26.2 \mathrm{~g}$; the intensity of grain filling was $1.74 \mathrm{~g} / \mathrm{day}$. On fertilizer background, variety 'Isolda' accumulated the highest amount of dry matter - $25.7 \mathrm{~g}$; the filling intensity was $183 \mathrm{~g} /$ day.

The study demonstrated that as 1000-grain weight increased after application of mineral fertilizers, the yield capacity of durum spring wheat varieties also increased. For example, over the study years on mineral fertilizer-free background, the average yield capacity across the varieties was $2.60 \mathrm{t} / \mathrm{ha}$, and when mineral fertilizers were added, it increased by $0.85 \mathrm{t} / \mathrm{ha}$ and was $3.45 \mathrm{t} /$ ha. The maximum 1000-grain weight without fertilizers was recorded for variety 'Spadschina' (45.7 g); and on fertilizer background - for variety 'Zhizel' (51.1 g), with the yield capacity of $2.66 \mathrm{t} / \mathrm{ha}$ and $3.44 \mathrm{t} /$ ha for these varieties, respectively.

There were average negative correlations with $r=-0.48$ and $r=-0.68$ between 1000-grain weight and yield capacity for mineral nutrition backgrounds, respectively.

Conclusions. The study established that all the durum spring wheat varieties belonged to the forest-steppe ecotype. The varieties accumulated the largest amounts of dry matter in the phase of milk ripeness (21.4-26.2 g), depending on a variety and mineral nutrition.

The maximum 1000-grain weight without fertilizers was recorded for variety 'Spadschina' (45.7 $\mathrm{g}$ ); and with $\mathrm{N}_{60} \mathrm{P}_{60} \mathrm{~K}_{60}$ application - for variety 'Zhizel' (51.1 g). The yield capacity, like 1000 -grain weight, increased on average across the varieties by $0.85 \mathrm{t} / \mathrm{ha}$ after fertilization. No significant difference between varieties was seen.

Key words: durum spring wheat, ecotype, grain filling, phase of development, variety, yield capacity 